\title{
IN VITRO INTERACTION OF CORONAVIRUSES WITH PRIMATE AND HUMAN BRAIN MICROVASCULAR ENDOTHELIAL CELLS
}

\author{
G. F. Cabirac ${ }^{1,2,3}$, R. S. Murray ${ }^{2,4}$, L. B. McLaughlin' ${ }^{1}$ D. M. Skolnick ${ }^{1}$, \\ B. Hogue ${ }^{5}$, K. Dorovini-Zis ${ }^{6}$, and P. J. Didier ${ }^{7}$ \\ ${ }^{1}$ Rocky Mountain Multiple Sclerosis Center \\ ${ }^{2}$ Colorado Neurological Institute \\ Swedish Medical Center, Englewood, Colorado \\ ${ }^{3}$ Department of Biochemistry, Biophysics and Genetics \\ University of Colorado Health Sciences Center \\ Denver, Colorado \\ ${ }^{4}$ National Jewish Center for Immunology and Respiratory Medicine \\ ${ }^{5}$ Department of Microbiology and Immunology \\ Baylor College of Medicine, Houston, Texas \\ ${ }^{6}$ Department of Pathology, University of British Columbia \\ Vancouver, British Columbia, Canada \\ ${ }^{7}$ Department of Pathology, Tulane Regional Primate Research Center \\ Covington, Louisiana
}

\begin{abstract}
Primary human and primate brain microvascular endothelial cells were tested for permissiveness to coronaviruses JHM and 229E. While sub-genomic viral RNAs could be detected up to 72 hours post-infection, primate cells were abortively infected and neither virus caused cytopathology. Human cells were non-permissive for JHM but permissive for $229 \mathrm{E}$ replication; peak production of progeny $229 \mathrm{E}$ and observable cytopathic effects occurred approximately 22 and 32 hour post-infection, respectively. Using the criterion of cytopathology induction in infected endothelial cells, 229E was compared to other human RNA and DNA viruses. In addition, virus induced modulation of intercellular adhesion molecule 1 (ICAM-1), vascular cell adhesion molecule 1 (VCAM-1) and HLA I was monitored by immunostaining of infected cells.
\end{abstract}




\section{INTRODUCTION}

While numerous studies of coronavirus infection in rodents has generated valuable information on the mechanisms of virus induced CNS disease ${ }^{1-7}$, the question of coronavirus CNS disease in humans justifiably remains open. Many viruses with confirmed neurotropic potential can infect the CNS of the host following primary infection at extra neural sites. Studies on natural infections of humans and on both natural and experimental infections of animals indicate that viruses enter the CNS primarily through the vascular endothelium ${ }^{8-10}$. Infection of CNS tissue may occur after virus replicates in or is transported through endothelial cells ${ }^{8,9}$. Because of reports linking coronaviruses to human CNS disease $\mathrm{e}^{11-13}$ and the observation that peripheral inoculation of JHM into primates results in viral RNA/antigen expression in areas proximal to CNS blood vessels ${ }^{14}$ we have chosen to characterize the in vitro interaction of coronaviruses with both primate and human brain microvascular endothelial cells.

\section{MATERIALS AND METHODS}

\section{Cells and Viruses}

DBT, WI-38, HCT, Vero and BSC-1 cells were grown in Dulbecco's modified Eagle's medium (DMEM; Gibco/BRL) supplemented with 10\% fetal bovine serum (FBS; Gibco/BRL), $100 \mathrm{U} / \mathrm{ml}$ penicillin and $100 \mu \mathrm{g} / \mathrm{ml}$ streptomycin. MHV JHM was obtained from Dr. Steve Stohlman ${ }^{2}$. JHM was assayed for hemagglutinating activity as previously described $^{15}$. Human coronavirus 229E was obtained from the American Type Culture Collection (ATCC). Vaccinia (WR strain), herpes simplex type I (HSV-I, strain F) and a clinical isolate of varicella zoster virus (VZV) were generous gifts from Dr. Donald Gilden. Vaccinia, HSV-I, JHM, 229E and OC43 were propagated and titered on BSC-1, Vero, DBT, WI-38 and HCT cells, respectively. $229 \mathrm{E}$ was grown at $34^{\circ} \mathrm{C}$ and all other viruses at $37^{\circ} \mathrm{C}$. Multiplicity of infection (m.o.i.) stated in this work, in reference to infection of endothelial cells, is calculated based on infectivity of the specific virus relative to its indicator cell line, e.g., 229E on WI38 cells.

UV-inactivation of JHM and 229E for use in RNA analysis was as follows. A volume of virus diluted in 5\% FBS medium was placed into a plastic dish so that the depth of liquid was approximately $2 \mathrm{~mm}$. Dishes were placed in ice- $\mathrm{H}_{2} \mathrm{O}$ and the inocula were exposed for 15 min to 15 watt $300 \mathrm{~nm}$ UV-light bulbs placed a distance of $5 \mathrm{~cm}$ from the surface of the liquid. Prior titration using this set-up showed that infectivity of either JHM on DBT or 229E on WI38 cells was completely eliminated after 5-10 minutes of UV exposure. Inactivated inocula were immediately used to infect cells used for RNA analysis.

Rhesus brain endothelial cells (RhBEC) were derived from animals in the breeding colony at Tulane Regional Primate Research Center (TRPRC) that were normally lost due to trauma and/or cachexia. Occasionally, control animals from other investigator projects were sacrificed. Animals of both sex and of all ages (none greater than 10 years of age) were used. No animals from studies involving infectious agents or drugs were used. Isolation and propagation of RhBEC was as follows. One-quarter to one-half of a monkey brain was generally used for this procedure. Brain tissue was stored in RPMI medium containing antibiotics and processed as soon as possible after collection. Meninges was removed from the brain and discarded then the tissue was put into approximately $100 \mathrm{ml}$ of Hanks balanced salt solution in a beaker. The tissue was chopped into small pieces, then cut into fine pieces against the side of the beaker using a scapel. The resulting pieces were homogenized by 
drawing the suspension in and out of a $10 \mathrm{ml}$ syringe. At this stage the tissue was processed using a Cellector (Bellco). If a large amount of tissue was used, processing was started with the $520 \mu \mathrm{m}$ screen, otherwise the $280 \mu \mathrm{m}$ screen was used. If the $520 \mu \mathrm{m}$ screen was used to start, the material on the screen was discarded and the suspension coming through the screen was saved for further use; on following screens the liquid coming through the screen was discarded and the material on screen was collected. When the homogenate became less dense and the liquid in the Cellector was reduced to approximately $10 \mathrm{ml}$, the $190 \mu \mathrm{m}$ screen was used until the liquid coming through cleared and the small vasculature could be seen sticking to the screen. The vasculature was rinsed from the $190 \mu \mathrm{m}$ screen (total volume equal to 9 $\mathrm{ml}$ ) and added to a small beaker. $1 \mathrm{ml}$ of $1 \%$ collagenase/dispase (Boehringer Mannheim) was added and the mixture incubated at $37^{\circ} \mathrm{C}$ with constant shaking for 1 hour. After incubation, $1 \mathrm{ml}$ of the suspension was placed into ten $60 \mathrm{~mm}$ dishes. These were rotated until the liquid evenly coated the dishes and then the dishes were allowed to incubate a few minutes undisturbed. 1-2 ml of medium was slowly added to each dish then endothelial growth factor was added to a final concentration of $100 \mu \mathrm{g} / \mathrm{ml}$. The dishes were incubated overnight at $37^{\circ} \mathrm{C}$ then the media discarded and replaced with fresh medium and growth factor. All cultures were stained with rabbit polyclonal anti-factor VIII-related antigen (fVIIIRAg) antibody (Dako) to verify phenotype. All endothelial cells used in this study were grown in Iscove's modified Dulbecco's medium, 20\% FBS, 100 $\mathrm{g} / \mathrm{ml}$ heparin (Sigma; H-3149), $100 \mathrm{U} / \mathrm{ml}$ penicillin and $100 \mu \mathrm{g} / \mathrm{ml}$ streptomycin (complete IMDM) supplemented with endothelial cell growth supplement (ECGS, Sigma; E2759) to a final concentration of $100 \mu \mathrm{g} / \mathrm{ml}$. Culture medium was changed every three days and confluent monolayers were passaged at a 1:3 to 1:6 split. Cultures were periodically stained for fVIIIRAg to monitor phenotype. All experiments with the RhBEC were done at or below a passage level of five.

The isolation and characterization of human brain endothelial cells (HBEC) has previously been described ${ }^{16-18}$. Cells were grown in M199 medium, $25 \mathrm{mM}$ HEPES, $10 \mathrm{mM}$ sodium bicarbonate, $10 \%$ FBS, $100 \mu \mathrm{g} / \mathrm{ml}$ heparin, $100 \mathrm{U} / \mathrm{ml}$ penicillin and $100 \mu \mathrm{g} / \mathrm{ml}$ streptomycin supplemented with $20 \mu \mathrm{g} / \mathrm{ml}$ ECGS on human fibronectin coated plastics (Corning). All virus infections were done on confluent HBEC monolayers. All experiments with the HBEC were done at or below a passage level of four.

\section{One-Cycle Virus Growth Assays}

Virus inocula were adsorbed to endothelial cell monolayers at $4^{\circ} \mathrm{C}$ for 30 minutes, unabsorbed virus was washed from monolayers by three rinses with cold medium then fresh medium added to monolayers; the zero time point samples were frozen immediately after addition of medium. At each time point duplicate or triplicate samples were frozen at $-70^{\circ} \mathrm{C}$. Time point samples were thawed and virus assayed on the appropriate indicator cell lines.

\section{RNA Analysis}

JHM and 229E inocula used for infection of RhBEC were in DME + 5\% FBS. JHM and $229 \mathrm{E}$ were adsorbed at $37^{\circ} \mathrm{C}$ and $34^{\circ} \mathrm{C}$, respectively, to monolayers for 1 hour. The monolayers were washed twice with warmed complete IMDM then complete IMDM + $100 \mu \mathrm{g} / \mathrm{ml}$ endothelial cell growth supplement was added. All 229E infected cultures were incubated at $34^{\circ} \mathrm{C}$. Total RNA was extracted from virus infected or mock infected cells by the single-step method of Chomczynski and Sacchi ${ }^{19}$. All reagents used for RNA analysis were prepared with water obtained from a PhotoCatalytics water system (PhotoCatalytics, Inc.). This instrument photoxidizes residual organic compounds in feed water not removed by conventional upstream water purification treatments; eluant water is free of RNases and therefore does not require diethylpyrocarbonate (DEPC) treatment before use in RNA 
manipulations ${ }^{20}$. Purified RNA was dissolved in $2 \mathrm{mM}$ EDTA and poly $\mathrm{A}^{+}$RNA prepared using Dynal Oligo $(\mathrm{dT})_{25}$ beads. Poly $\mathrm{A}^{+} \mathrm{RNA}$ samples were glyoxylated and electrophoresed on $1.0 \%$ agarose gels as described previously ${ }^{21}$. RNA was transferred to membranes (Nytran Plus, Schleicher \& Schuell) by electroblotting in $40 \mathrm{mM}$ Tris acetate, $1 \mathrm{mM}$ EDTA(1X TAE buffer) at $4^{\circ} \mathrm{C}$ then immobilized by baking the membrane in a vacuum oven at $70-80^{\circ} \mathrm{C}$ for 1 hour. The cloned cDNA probes used to detect JHM and 229E RNA were cDNA clones G344 and L8, respectively ${ }^{22,23}$. cDNA was labeled by the random primer method ${ }^{24}$ with $\alpha^{32} \mathrm{P}$ dATP. Membranes were prehybridized in 50\% deionized formamide, 10X Denhardt's, $2 \%$ SDS, $5 \mathrm{X}$ SSPE, and $200 \mu \mathrm{g} / \mathrm{ml}$ single-stranded DNA at $44^{\circ} \mathrm{C}$ for 3 hours. Prehybridization buffer was removed, the membrane briefly rinsed in warmed hybridization buffer (without probe) then hybridization buffer containing denatured probe at $1 \times 10^{6} \mathrm{cpm} / \mathrm{ml}$. Hybridization buffer was $50 \%$ deionized formamide, $5 \mathrm{X}$ Denhardt's, $0.2 \%$ SDS, $5 \mathrm{X}$ SSPE, and $100 \mu \mathrm{g} / \mathrm{ml}$ DNA. Hybridization was at $44^{\circ} \mathrm{C}$ for $16-18$ hours. Membranes were washed twice in $5 \mathrm{X}$ SSPE, $0.1 \%$ SDS for 15 minutes each, once in $1 \mathrm{X}$ SSPE, $0.2 \%$ SDS for 15 minutes, and once in $0.1 \mathrm{X}$ SSPE, $0.2 \%$ SDS for 15 minutes, all washes done at room temperature. A final wash was done in $1 \mathrm{X} \mathrm{SSPE}, 1.0 \% \mathrm{SDS}$ at $60^{\circ} \mathrm{C}$ for 30 minutes.

\section{Immunohistochemical Staining}

Monoclonal antibodies specific for human inter-cellular adhesion molecule 1 (ICAM-1), vascular cell adhesion molecule 1 (VCAM-1), and HLA-I, were obtained from commercial sources (Genzyme and Becton Dickinson). MAbs J.3.1 specific for JHM nucleocapsid and 5-11H.6 specific for 229E spike glycoprotein were gifts from Dr. John Fleming and Dr. Pierre Talbot, respectively. Cells used for staining were grown on either glass cover slips or 8-chambered plastic slides (Nunc) that were coated with fibronectin (described above) prior to seeding. Cells were briefly washed in cold serum-free medium, fixed in $-20^{\circ} \mathrm{C}$ methanol for 10 minutes then washed three times in phosphate-buffered saline (PBS). Fixed monolayers were incubated with 5\% normal goat serum (NGS) in PBS, $0.1 \%$ BSA for 20 minutes followed by primary antibody diluted in PBS, $0.1 \%$ BSA, $2 \%$ NGS for 1 hour. Monolayers were washed three times for 10 minutes each in PBS, incubated with gold-cojugated goat anti-mouse antibody (Amersham AuroProbeLM) for 1 hour, washed three times in PBS then three times in $\mathrm{H}_{2} \mathrm{O}$ for 5 minute each. Bound, gold-conjugated antibody was detected by silver staining (Amersham IntenSEM) using the manufacturers recommended conditions.

\section{RESULTS}

\section{Virus Replication on Brain Endothelial Cells and Cytopathic Effects}

Standard one-cycle replication assays of JHM or 229E on RhBEC or HBEC showed that HBEC were permissive for 229E but not JHM and that RhBEC were non-permissive for both 229E and JHM (Figure 1). Each virus was tested for production of progeny virus from both RhBEC and HBEC on one animal/patient cell isolate. Peak titers of progeny 229E from infected HBEC occurred approximately $22 \mathrm{hr}$ p.i.; input infectious JHM or 229E in RhBEC or JHM in HBEC decayed over the observed time course.

For the coronaviruses tested there was a correlation of CPE to productive infection, i.e., 229E but not JHM was cytopathic for HBEC and neither virus was cytopathic for RhBEC. Figure 2 shows mock infected HBEC and 229E infected HBEC, A and B, respectively. 229E induced cytopathology was observable on infected monolayers approximately $32 \mathrm{hr}$ p.i.. To compare these coronaviruses to other common human viruses, the brain 
Figure 1. One-cycle virus replication assays on RhBEC and HBEC Titer values shown represent cell associated plus extracellular virus in cultures at each time point

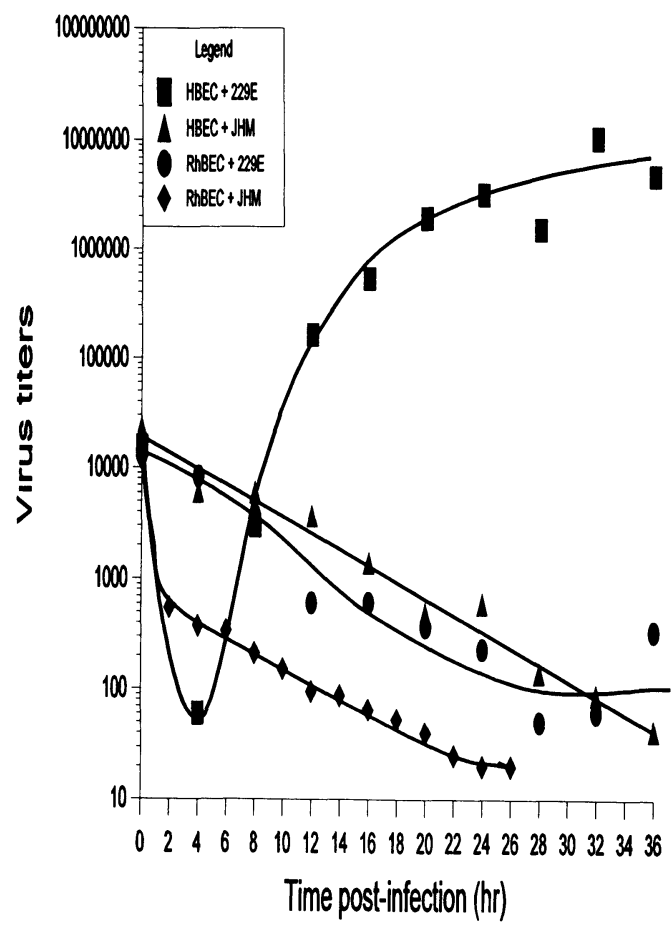

endothelial cells were infected with a number of RNA and DNA viruses. Table 1 shows the tested viruses that were cytopathic or non-cytopathic for either RhBEC or HBEC. Three to five RhBEC isolates were used to test for CPE induction by each virus (left column); all virus infections of HBEC (right column) were done on one patient isolate.

\section{Viral Antigen and RNA Production in Infected Cells}

Immunostaining of $229 \mathrm{E}$ or JHM infected RhBEC monolayers with virus specic monoclonal antibodies showed that virus antigens were detectable up to $48 \mathrm{hr}$ p.i.. Despite the presence of viral sub-genomic RNA in the infected cells (see below), the pattern of staining suggested that these antigens were from input virus and not from de novo synthesis in the cells; staining of JHM infected HBEC showed the same pattern of antigen as in the primate cells (data not shown). Staining with 229E specific MAb showed cytoplasmic viral
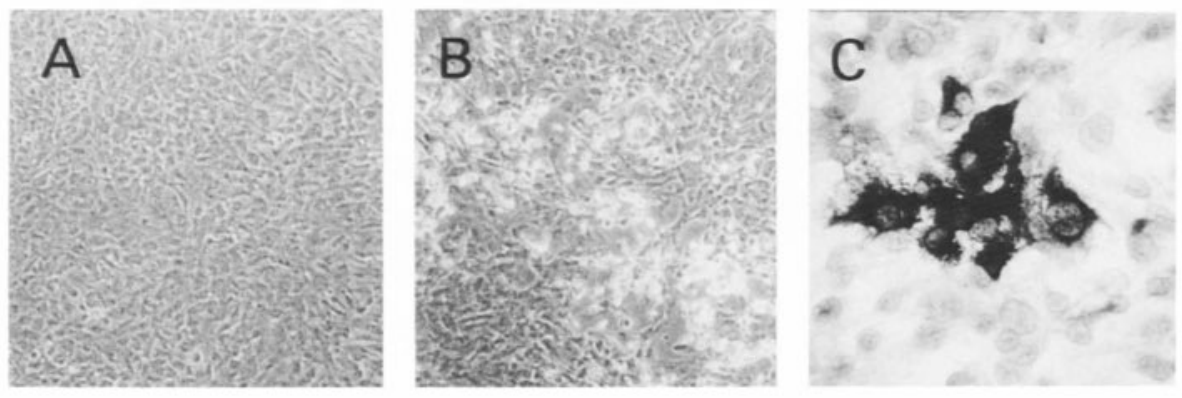

Figure 2. 229E CPE on HBEC and stainıng of viral antigen A, Mock infected HBEC, B, 229E infected HBEC $\sim 38 \mathrm{hr}$ p 1 ; C, 229E infected HBEC immunostained showing cytoplasmic viral antıgen $(\sim 14 \mathrm{hr} \mathrm{p} 1)$ 
Table 1. Virus Induced Cytopathology in RhBEC and HBEC

\begin{tabular}{lc}
\hline RhBEC $^{\text {a }}$ & HBEC $^{\text {b }}$ \\
\hline $\begin{array}{l}\text { Cytopathic viruses tested: } \\
\text { Vaccinia }\end{array}$ & $\begin{array}{c}\text { Cytopathic viruses tested: } \\
\text { Vaccinia }\end{array}$ \\
Herpes simplex type $1^{\mathrm{c}}$ & Herpes simplex type 1 \\
& Varicella zoster virus \\
& Adenovirus types 1 \& 7 \\
& Echovirus type 9 \\
& Coxsackievirus B5 \\
& Coronavirus 299E \\
\hline Non-cytopathic viruses tested: & Non-cytopathic viruses tested: \\
Coronaviruses: & Human cytomegalovirus \\
JHM & Respiratory syncytial virus \\
SD & Parainfluenza virus type 2 \\
$229 E$ & Coronaviruses: \\
OC43 & JHM \\
& SD \\
& OC43
\end{tabular}

${ }^{\mathrm{a}}$ All viruses listed were tested on three to five different animal isolates.

${ }^{b}$ Viruses were tested on one patient isolate only.

${ }^{c} \mathrm{HSV}-1$ induced CPE was dependent on the animal isolate tested; some isolates developed no CPE while other isolates were affected.

${ }^{\mathrm{d}} \mathrm{SD}$ designates putative MS tissue isolate ${ }^{11}$.

'Towne strain.

All viruses not described in Materials and Methods were obtained from the American Type Culture Collection and propagated on appropriate cell lines.

antigen in productively infected HBEC (Fig. 2C). Staining of OC43 infected RhBEC or HBEC with an OC43 cross-reactive HEV MAb (4E11.3) showed similar pattern of staining to JHM or 229E non-productively infected cells (data not shown).

Analysis of poly $\mathrm{A}^{+} \mathrm{RNA}$ extracted from infected RhBEC showed that subgenomic RNAs were transcribed in both JHM and 229E infected endothelial cells. Figure 3 shows

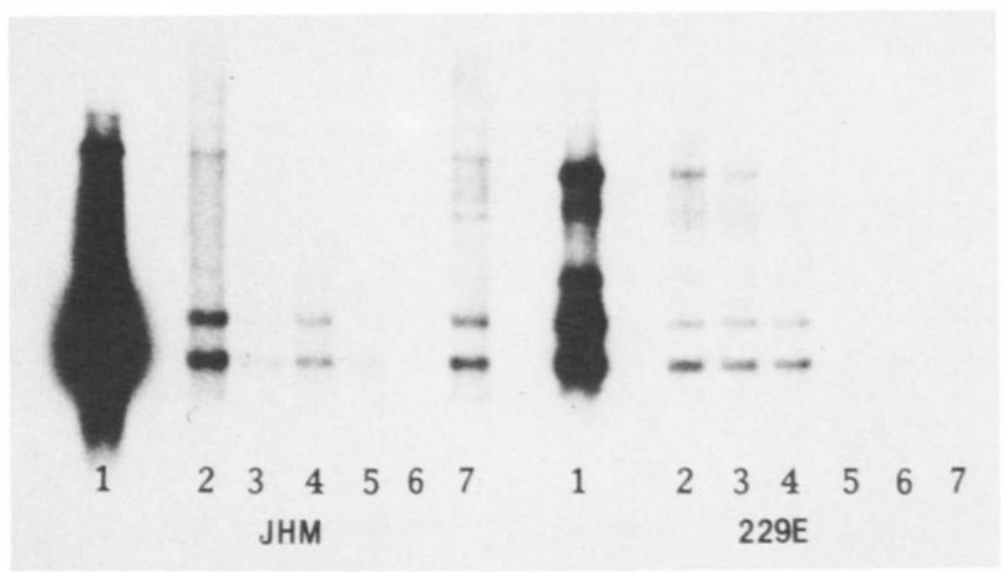

Figure 3. Northern analysis of RNA from JHM and 229E infected RhBEC. See text for description. 
samples extracted 2, 8 and 24 hours p.i. from endothelial cells (JHM, left lanes 2, 4, 7;229E, right lanes 2-4). For both JHM and 229E the highest level of these transcripts appears to be at the 2 hour p.i. time point. Based on a comparison between the amount of RNAs loaded onto the gel and the autoradiographic signals, the quantities of JHM and 229E RNAs in the endothelial cells, at time of maximum production, are only $1-5 \%$ of the quantities in normal productively infected cells (DBT+JHM, left lane 1; WI38+229E, right lane 1). Despite the low levels produced in the endothelial cells, viral RNAs could be detected as late as 72 hours p.i. (data not shown). These results were repeatable for 229E and JHM with cells isolated from 2 and 5 different animals, respectively.

Infection of RhBEC with UV inactivated virus showed that production of detectable viral RNAs in cells was significantly reduced for JHM (lane 5) and 229E (lane 5). Using the same UV inactivated inocula and running approximately equivalent amounts of RNAs on the gel, JHM RNA could not be detected in infected DBT cells (JHM, lane 6 ) and a only a minor amount of 229E RNA could be detected in infected WI38 (2289E, lane 6). Viral RNAs could also be detected in JHM infected WI38 cells (JHM, lane 7) and 229E infected DBTs (229E, lane 7). RNA analysis was not done on virus infected HBEC.

\section{ICAM-1, VCAM-1 AND HLA-I Expression on Infected HBEC}

Infected HBEC monolayers were immunostained for ICAM-1, VCAM-1 and HLA-I to determine if virus can modulate expression of these cell surface antigens (Table 2). It appeared that there was an increase in ICAM-1 expression in both HSV-1 and 229E infected HBEC at $14 \mathrm{hr}$ p.i.; vaccinia infected cells maintained base level of ICAM-1 expression. TNF $\alpha$ caused an expected large increase in ICAM-1 expression. No change in VCAM-1 expression was observed at $14 \mathrm{hr}$ p.i. with the viruses tested. Similarly, HLA-I expression was not affected by any of the viruses tested or, unexpectedly, by TNF $\alpha$.

\section{DISCUSSION}

Because the reticuloendothelial system clears hematogenous virus during most in vivo viremic infections the amount of cell-free virus in blood is usually low. Despite this, the vascular endothelium is the major route for natural CNS infection by viruses. Therefore to approximate one of the many factors involved in an in vivo CNS virus infection we have characterized the in vitro interaction of viruses with cultured brain endothelial cells. $\mathrm{Cy}$ topathology, virus replication and modulation of specific cell surface polypeptides were the criteria used to characterize coronavirus interaction with RhBEC and HBEC; the coronaviruses were also compared to other common human viruses.

Table 2. ICAM-1, VCAM-1 and HLA-I expression on virus infected HBEC

\begin{tabular}{lccc}
\hline & ICAM-1 & VCAM-1 & HLA-I \\
\hline Mock & + & \pm & \pm \\
TNF $\alpha$ & +++ & ++ & \pm \\
Vaccinia & + & \pm & \pm \\
HSV-1 & ++ & \pm & \pm \\
$229 \mathrm{E}$ & ++ & \pm & \pm \\
\hline
\end{tabular}

Cells stained $\sim 14 \mathrm{hr}$. post-infection/treatment 
The rationale for using brain microvascular endothelial cells for this study is that there is evidence of endothelial cell phenotype heterogeneity that is dependent on tissue/organ origin. Endothelial cells isolated from specific vascular beds exhibit differences in expression of a number of markers when cultured in vitro and they maintain these differences over short-term passage ${ }^{25-28}$. In addition, there are also differences in response to virus infection when comparing tissue/organ specific endothelial cells ${ }^{29-32}$. Obviously, biological properties of cultured endothelial cells will not be identical to those of cells in vivo because of losing the modifying influence of the in vivo milieu. This has been shown for brain endothelial cells where extracellular matrix proteins, soluble factors released from astrocytes or even cell-cell contact with astrocytes can alter expression of certain markers ${ }^{33}$. Accurate in vitro determination of in vivo brain endothelial cell response to virus infections will probably require culturing the cells in the presence of these various modifying factors.

For JHM and 229E, induction of cytopathology in infected cells was predictive of a productive infection (see Fig. 1 and Table 1). Interestingly, when looking at the other viruses tested on HBEC there appeared to be a correlation between virus CPE and incidence of clinical CNS diseases ${ }^{34}$. Viruses that are known to cause encephalitis or meningitis produced cytopathology while viruses not identified as causative agents of CNS infection, e.g., RSV, did not induce CPE. Other than the coronaviruses, we did not confirm that CPE always indicated a productive infection or that lack of $\mathrm{CPE}$ was associated with a non-productive infection.

While neither JHM or 229E caused RhBEC cytopathology, the detection of viral sub-genomic RNA species indicates that a percentage of input virions uncoated in a manner that permitted some transcription of the virus genome. The results obtained from infection with UV-inactivated virus indicates that these RNAs were not present as a result of packaging in inoculum virions as demonstrated for $\mathrm{BCV}^{35}$, $\mathrm{TGEV}^{36}$, and $\mathrm{IBV}^{37}$. Preliminary immunoprecipitation experiments with JHM infected RhBEC showed that nucleocapsid was not synthesized (data not shown). This suggests that at least one block in virus replication in $\mathrm{RhBEC}$ occurs at the step of viral mRNA translation; this result also indicates that $\mathrm{N}$ detected by immunostaining of infected cells was from input virus. Since viral RNAs were detected in the non-permissive endothelial cells the question of receptor mediated versus non-specific entry of the viruses needs to be addressed. It is important to note that the stocks of JHM used for this work did not have hemagglutination activity.

We immunostained ICAM-1, VCAM-1 and HLA-I on infected HBEC as a preliminary test to determine the effects of $229 \mathrm{E}$ on expression of endothelial cell surface antigens that are important in an immune response. ICAM-1 was the only one of the three cell-surface polypeptides affected at $\sim 14 \mathrm{hr}$ p.i.; the staining showed that the number of cells expressing elevated levels of ICAM-1was greater than the number of expected infected cells. This suggests that for 229E infected HBEC, ICAM-1 elevation was the result of secretion of some soluble mediator. This would be similar to the observation that CMV infection causes endothelial cells to secrete IL-1 resulting in upregulation of another adhesion molecule, $\mathrm{E}$ selectin $^{38}$. Endothelium surface antigens may be differentially regulated by coronaviruses depending on the virus and host species since it has been reported that JHM causes a decrease in ICAM-1 expression on murine brain endothelial cells ${ }^{39}$.

Endothelial cells play a crucial role in the control of inflammation, coagulation, leukocyte trafficking, tumor metastasis, and angiogenesis. The endothelium specific modulation of these processes is mediated by both endothelial cell associated molecules and secreted, soluble factors. During either a nonspecific, acute phase immune response or an antigen-specific, DTH response the expression of both cell associated and secreted biomolecules by the affected endothelial cells can be altered by infecting virus. For coronaviruses, a more thorough examination of virus interaction with endothelial cells is warranted. In addition to the data showing 229E infection of HBEC, the results with JHM 
suggest that other coronavirus strains have the potential to enter endothelial cells and undergo limited transcription, the possibility exist that endothelium specific factors are modulated despite a lack of virus replication It will be important to determine the effects of coronaviruses on the physiologic or pathophysiologic processes that occur at the CNS endothelium in humans

\section{REFERENCES}

1 Sorensen, O, Percy, D and Dales, S In vivo and in vitro models of demyelinating diseases III JHM virus infection of rats Arch Neurol 1980, 37 478-484

2 Stohlman, S A and Weiner, L P Chronic central nervous system demyelination in mice after JHM virus infection Neurol 1981, 31 38-44

3 Knobler, R , Haspel, M , and Oldstone, M Mouse hepatıtıs virus type-4 (JHM strain) - Induced fatal central nervous system disease I Genetic control and the murine neuron as the susceptible site of disease J Exp Med 1981, 153832

4 Dubois-Dalcq, M E, Doller, E W, Haspel, M U , and Holmes, K Cell tropism and expression of mouse hepatitıs viruses (MHV) in mouse spinal cord cultures Virol 1982, 119 317-331

5 Lavı, E, Gilden, D H , Highkın, M K and Weıss, S Persistence of mouse hepatitıs virus A59 RNA in a

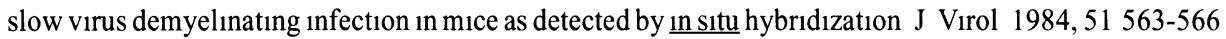

6 Buchmeier, M , Lewickı, H, Talbot, P, and Knobler, R Murıne hepatitıs virus-4 (strain JHM) induced neurologic disease is modulated $i n$ vivo by monoclonal antibody Virol 1984, 132261

7 Perlman, S , Jacobsen, G and Afifi, A Spread of a neurotropic murıne coronavirus into the CNS via the trigeminal and olfactory nerves Virol 1989, 170556

8 Johnson R T Viral Infections of the Nervous System New York Raven Press, 1982

9 Mims C A The Pathogeneis of Infectious Diseases 2nd ed London Academic Press, 1982

10 Johnson R T and Mims C A Pathogenesis of viral infections of the nervous system N Engl J Med 1968 , 278 23-30,87-92

11 Burks, J S, DeVald, B L, Jankovsky, L D, and Gerdes, J C Two coronaviruses isolated from central nervous system tissue of two multiple sclerosis patients Science 1980, 209 933-934

12 Murray R S, Brown, B, Brian, D, and Cabırac, G F Detection of coronavirus RNA and antigen in multıple sclerosıs brain Ann Neurol 1992, 31 525-533

13 Stewart, J N , Mounır, S , and Talbot, P J Human coronavirus gene expression in the brain of multıple sclerosis patients Virol 1992, 191 502-505

14 Cabırac, G F, Sorke, K F, Hoel, K, Butunol, C, Ca1, G -Y, Johnson, S, and Murray, R S Entry of coronavirus into primate CNS following peripheral infection Micro Path 1994,

15 Hogue, B G and Brian, D A Structural proteins of human respiratory coronavirus OC43 Virus Res 1986, 5 131-144

16 Dorovinı-Z1s K , Prameya R , and Bowman P D Culture and characterızation of microvascular endothelial cells derived from human brain Lab Invest 1991, 64 425-436

17 Wong D and Dorovinı-Z1s K Upregulation of intercellular adhesion molecule-1 (ICAM-1) expression in primary cultures of human brain microvessel endothelial cells by cytokınes and lipopolysaccharide J Neuroimmunol 1992, 39 11-21

18 Huynh, H K and Dorovinı-Zis K Effects of interferon-gamma on primary cultures of human brain microvessel endothelial cells Amer J Path 1993, 142 1265-1278

19 Chomczynskı, P and Sacchı, N Single-step method of RNA 1solation by acid guanıdınıum thıcyanatephenol-chloroform extraction Anal Biochem 1987, 162 156-159

20 Cooper, G, Borısh, L, Mascalı, J, Watson, C, Kırkegaard, K, Morrissey, L, and Tedesco, J L The photocatalytıc production of organıc-free water for molecular biological and pharmaceutical applications J Biotech 1994, 33 123-133

21 Cabırac, G F, Mulloy, J J , Strayer, D S, Sell, S, and Leıbowitz, J L (1986) Transcriptıonal mapping of early RNA from regions of the Shope fibroma and malignant rabbit fibroma virus genomes Virol 1986, 153, 53-69

22 Budzilowicz, C J, Wilczynskı, S P, and Weiss, S R Three intergenic regions of coronavirus mouse hepatitıs virus strain A59 genome RNA contain a common nucleotide sequence that is homologous to the 3' end of the viral mRNA leader sequence Virol 1985, 53 834-840

23 Schreıber, S S, Kamahora, T, and Laı, M M C Sequence analysis of the nucleocapsid protein gene of human coronavirus 229E Virol 1989,169 141-151 
24 Feınberg, A P, and Vogelsteın, B A technıque for radıolabelıng DNA restrıction endonuclease fragments to high specific activity Anal Biochem 1983, 132 6-13

25 Gumkowskı, F, Kamınska, G , Kamınsk1, M , Morrıssey, L W , and Auerbach, R Heterogeneity of mouse vascular endothelium In vitro studies of lymphatic, large blood vessel and microvascular endothelial cells Blood Vessels 1987, 24 11-23

26 Turner, R R, Beckstead, J H, Warnke, R A, and Wood, G S Endothelial cell phenotypic diversity In situ demonstration of immunologic and enzymatic heterogeneity that correlates with specific morphologic subtypes Amer J Clin Path 1987, 87 569-576

27 Belloni, PN and Nicolson, G L Differential expression ofcell surface glycoproteins on various organ derived microvascular endothelia and endothehial cell cultures J Cell Physiol 1989, 136 398-410

28 Lodge, P A, Haisch, C E, Huber, S A, Martın, B, and Craighead, J C Biological differences in endothelial cells depending upon organ derivation Transplant Proc 1991, 23 216-218

29 Huber, S A , Haisch, C , and Lodge, PA Functional diversity in vascular endothelial cells role in coxsackievirus tropism J Virol 1990, 64 4516-4522

30 Goerdt, S and Sorg, C Endothelial heterogeneity and the acquired immunodeficiency syndrome a paradıgm for the pathogenesis of vascular disorders Clin Investıg 1992, 70 89-98

31 Lafon, M E , Gendrault, J L , Royer, C , Jaeck, D , Kırn, A , and Steffan, A M Human endothelıal cells isolated from the hepatic sinusoids and the umbilical vein display a different permissiveness for HIVI Res Virol 1993, 144 99-104

32 Joseph, J , Kım, R, Siebert, K , Lublın, F D , Offenbach, C , and Knobler, R L Organ specific endothelıal cell heterogeneity influences differential replication and cytopathogenicity of MHV-3 and MHV-4 Implicatıons in viral tropısm In Adv Expt Med Bıol, (eds) Talbot P and Levy G 1995 Plenum Press, NY $p 43$

33 Abbott, N J , Revest, P A , and Romero, I A Astrocyte-endothelial interaction physiology and pathology Neuropath App Neurobiol 1992, 18 424-433

34 In Principles and Practice of Infectious Diseases (3rd Ed) (eds) Mandell, G L , Douglas, R G , and Bennett, J E 1990 Churchill Livingstone Inc

35 Hofmann, M A, Sethna, P B , and Brian, D A Bovine coronavirus mRNA replication contınues throughout persistent infection in cell culture J Virol 1990, 64 4108-4114

36 Sethna, PB , Hofmann, M A , and Brian, D A Minus-strand copıes of replicatıng coronavirus mRNAs contain antileaders J Virol 1991, 65 320-325

37 Cavanagh, D, Shaw, $\mathrm{K}$, and Xiaoyan, $\mathrm{Z}$ Analysıs of messenger RNA withın virions of IBV In Adv Expt Med B1ol, Vol 342 (eds) Laude H and Vautherot J-F 1993 Plenum Press, NY

38 Span, A H, Mullers, W, Miltenburg, A M , and Bruggeman CA Cytomegalovirus induced PMN adherence in relation to an ELAM-1 antigen present on infected endothelial cell monolayers Immunol 1991, $72355-360$

39 Joseph, J, Knobler, R L, Lublın, F D, and Burns, F R Regulation of the expression of intercellular adhesion molecule-1 (ICAM-1) and the putative adhesion molecule basigin on murine cerebral endothelial cells by MHV-4 (JHM) In Adv Expt Med Bıol, Vol 342 (eds) Laude H and Vautherot J-F 1993 Plenum Press, NY 